\title{
Correction: Cocaine- and stress-primed reinstatement of drug- associated memories elicit differential behavioral and frontostriatal circuit activity patterns via recruitment of L-type $\mathrm{Ca}^{2+}$ channels
}

Charlotte C. Bavley · Robert N. Fetcho • Caitlin E. Burgdorf • Alexander P. Walsh • Delaney K. Fischer • Baila S. Hall $($ D Nicole M. Sayles · Natalina H. Contoreggi - Jonathan E. Hackett · Susan A. Antigua - Rachel Babij •

Natalia V. De Marco García · Thomas L. Kash · Teresa A. Milner · Conor Liston · Anjali M. Rajadhyaksha

Published online: 6 December 2019

(c) Springer Nature Limited 2019

\section{Correction to: Molecular Psychiatry}

https://doi.org/10.1038/s41380-019-0513-2

published online 09 September 2019
Following publication, the authors noticed that 'Natalia V. De Marco García' was inadvertently omitted from the author list. This author has now been added to the author list in 12th position. This has been corrected in both the PDF and HTML versions of the article. 